\title{
Short communication: Fat-soluble vitamin and mineral status of milk replacer-fed dairy calves: Effect of growth rate during the preruminant period ${ }^{1}$
}

\author{
B. J. Nonnecke, ${ }^{* 2}$ M. R. Foote,$\dagger^{3}$ B. L. Miller, $\ddagger$ D. C. Beitz, $\nmid$ and R. L. Horst ${ }^{* 4}$ \\ *USDA-ARS-National Animal Disease Center, Bldg 24, 1920 Dayton Ave., PO Box 70, Ames, IA 50010 \\ †Department of Animal Science, lowa State University, Ames 50011 \\ łLand O'Lakes Inc., 1025-190th St., PO Box 65, Webster City, IA 50595
}

\begin{abstract}
Effects of growth rate on fat-soluble vitamin and macro- and micromineral concentrations in the circulation of preruminant dairy calves were evaluated. Dietary treatments were designed to achieve 3 targeted rates of gain $[$ no growth $(\mathrm{NG})=0.0 \mathrm{~kg} / \mathrm{d}$; low growth $(\mathrm{LG})=$ $0.55 \mathrm{~kg} / \mathrm{d}$; or high growth $(\mathrm{HG})=1.2 \mathrm{~kg} / \mathrm{d}]$ over a 7 -wk period. Milk replacer (MR) intakes necessary to achieve these growth rates were estimated using the National Research Council's Nutrient Requirements of Dairy Cattle calf model computer program. All of the calves were fed a $30 \%$ crude protein, $20 \%$ fat MR reconstituted to $14 \%$ dry matter. The diets were formulated to ensure that protein was not a limiting nutrient. No-growth and LG calves were supplemented additionally with vitamins $\mathrm{A}, \mathrm{D}$, and $\mathrm{E}$ to compensate for treatment differences in dry matter intake relative to the HG calves; however, no attempt was made to adjust mineral intake based on MR consumption. Growth rates for NG (0.11 $\mathrm{kg} / \mathrm{d})$, LG $(0.58 \mathrm{~kg} / \mathrm{d})$, and HG $(1.16 \mathrm{~kg} / \mathrm{d})$ calves differed during the study. Health was minimally affected by growth rate and this was reflected by comparable and relatively low serum haptoglobin concentrations in all calves during the 7 -wk period. Concentrations of serum retinol, 25-(OH)-vitamin $\mathrm{D}_{3}$, and zinc were unaffected by growth rate. The HG calves had lower $R R R$ - $\alpha$-tocopherol concentrations than $\mathrm{NG}$ and $\mathrm{LG}$ calves at wk 7 , suggesting that the increased growth rate of $\mathrm{HG}$ calves was associated with increased utilization of vitamin E. Serum concentrations of all vitamins increased with age. Copper, calcium, and phosphorous concentrations in $\mathrm{HG}$ calves exceeded those in LG
\end{abstract}

Received November 9, 2009.

Accepted February 13, 2010.

${ }^{1}$ Names are necessary to report factually on available data; however, the USDA neither guarantees nor warrants the standard of the product, and the use of the name by the USDA implies no approval of the product to the exclusion of others that may also be suitable.

${ }^{2}$ Corresponding author: brian.nonnecke@ars.usda.gov

${ }^{3}$ Current address: Department of Animal Science, Cornell University, Ithaca, NY 14853.

${ }^{4}$ Current address: Heartland Assays Inc., Ames, IA 50010. and NG calves during the latter weeks of the study, likely because of increased MR intake by $\mathrm{HG}$ calves. Fat-soluble vitamin and mineral concentrations for all treatment groups remained within ranges considered normal for preruminant calves.

Key words: preruminant calf, vitamins A, D, and E, mineral status

The importance of nutrient supply on body composition and growth performance of preruminant calves has been evaluated extensively. Consequences of increased growth rate, associated with enhanced early nutrition, on fat-soluble vitamin status and mineral status of dairy calves fed milk replacer (MR) have not been investigated.

Vitamin A plays a vital role in vision, growth, and bone formation; vitamin $\mathrm{E}$ is a potent lipid-phases antioxidant; and vitamin D is a key regulator of calcium and phosphorus homeostasis. All 3 vitamins are recognized as being essential in ensuring optimal immune function and infectious disease resistance. At birth, dairy calves have very low plasma concentrations of vitamin A (retinol, $<40 \mathrm{ng} / \mathrm{mL})$, vitamin $\mathrm{E}(R R R$ - $\alpha$ tocopherol, $<200 \mathrm{ng} / \mathrm{mL}$; Nonnecke et al., 1999), and vitamin $\mathrm{D}$ [25-hydroxyvitamin $\mathrm{D}_{3}\left(25(\mathrm{OH}) \mathrm{D}_{3}\right), 20-25$ ng/mL; Rajaraman et al., 1997; Nonnecke et al., 2009] compared with adult dairy cows (retinol, 400-700 ng/ $\mathrm{mL}, R R R$ - $\alpha$-tocopherol $>500 \mathrm{ng} / \mathrm{mL}$, and $25(\mathrm{OH}) \mathrm{D}_{3}$, 45-80 ng/mL; Horst et al., 1994; Goff et al., 2001). Feeding colostrum within hours after birth induces a substantial increase in circulating concentrations of retinol and $R R R$ - $\alpha$-tocopherol but has no effect on $25(\mathrm{OH}) \mathrm{D}_{3}$ status (Rajaraman et al., 1997). Producers feed MR containing high concentrations of these vitamins to ensure adequate vitamin status and may administer, parenterally, fat-soluble vitamins within hours after birth. The most recent recommendations (NRC, 2001) regarding the nutrient requirements of dairy calves increased the vitamin A $(9,000 \mathrm{IU} / \mathrm{kg}$ of $\mathrm{DM})$ and vitamin $\mathrm{E}(50 \mathrm{IU} / \mathrm{kg}$ of $\mathrm{DM})$ requirements for MR-fed calves. The vitamin D requirement (600 IU/ $\mathrm{kg}$ of DM) was not increased from the previous recom- 
mendation, although commercial MR typically provide 10 - to 20 -fold more vitamin D than the current NRC (2001) recommendation.

The essential roles of $\mathrm{Ca}, \mathrm{Mg}$, and $\mathrm{P}$ in nerve and muscle function, bone formation, and metabolic disorders of dairy cattle were reviewed by Goff (2004). The normal range for plasma $\mathrm{Ca}$ is 9 to $10 \mathrm{mg} / \mathrm{dL}$ in the adult cow and slightly higher in calves (NRC, 2001). Deficiency in growing calves is manifested by suboptimal growth and, to a lesser extent, rickets. Normal plasma $\mathrm{Mg}$ concentrations in the calf range from 2.2 to $2.7 \mathrm{mg} / \mathrm{dL}$ (Roy, 1990) compared with 1.8 to $2.4 \mathrm{mg} /$ dL for adult dairy cows (NRC, 2001). Deficiency usually occurs in rapidly growing calves fed large amounts of milk or milk substitute and with no access to other supplementary feeds (Roy, 1990). Clinical symptoms are similar to those of Mg-deficient cows (i.e., excitability, uncoordinated gate, tetany) and may not be evident until plasma concentrations are $<0.7 \mathrm{mg} / \mathrm{dL}$. Plasma $\mathrm{P}$ concentrations in replete cattle range from 4 to $8 \mathrm{mg} /$ $\mathrm{dL}$, with growing cattle typically having concentrations at the higher end of this range $(6$ to $8 \mathrm{mg} / \mathrm{dL}$; NRC, 2001). Nonspecific signs of chronic deficiency (2 to 3.5 $\mathrm{mg} / \mathrm{dL}$ ) in the calf may be poor growth and possibly rickets in cases of severe deficiency.

Copper functions as a cofactor for enzymes involved with aerobic respiration, cross-linking of collagen, detoxification of oxygen metabolites, and transport of ferric iron in peripheral blood. Plasma $\mathrm{Cu}$ concentrations in normal preruminant calves range from 0.7 to $1.3 \mu \mathrm{g} / \mathrm{mL}$, whereas marginal deficiency occurs when concentrations are $<0.6 \mu \mathrm{g} / \mathrm{mL}$. Concentrations in the newborn calf are low $(<0.30 \mu \mathrm{g} / \mathrm{mL})$ but increase to near-adult levels (approximately $1 \mu \mathrm{g} / \mathrm{mL}$ ) within the first week of life. Symptoms of deficiency may not be evident until concentrations are $<0.2 \mu \mathrm{g} / \mathrm{mL}$ (Suttle, 1986). Zinc is intimately associated with numerous metalloenzymes affecting carbohydrate, protein, and lipid metabolism and is a component of thymosin, a key regulator of T-cell-mediated immunity. Although the normal range for plasma $\mathrm{Zn}$ concentrations in the preruminant calf is not established, the range in adult dairy cows is 0.7 to $1.3 \mu \mathrm{g} / \mathrm{mL}$, with deficiency occurring at $<0.4 \mu \mathrm{g} / \mathrm{mL}(\mathrm{NRC}, 2001)$.

The objective of this study was to evaluate the effect of growth-rate during the neonatal period on serum concentrations of retinol (VitA), $R R R$ - $\alpha$-tocopherol (VitE), and $25(\mathrm{OH}) \mathrm{D}_{3}$ (VitD) and minerals (Ca, P, $\mathrm{Mg}, \mathrm{Zn}, \mathrm{Cu}$ ) in calves fed $\mathrm{MR}$ at different rates to achieve targeted daily rates of gain representing no growth (NG), low growth $(\mathbf{L G})$, and high growth (HG).

Calf-related procedures were approved by the Animal Care and Use Committee of the National Animal
Table 1. Partial listing of milk replacer components ${ }^{1}$

\begin{tabular}{lc}
\hline Component & Analysis \\
\hline CP, \% of DM & 30.10 \\
Crude fat, \% of DM & 20.30 \\
Lactose, \% of DM & 32.65 \\
Calcium, \% of DM & 0.90 \\
Phosphorous, \% of DM & 0.84 \\
Magnesium, \% of DM & 0.12 \\
Copper, mg/kg & 10.08 \\
Zinc, mg/kg & 41.79 \\
Vitamin A, IU/kg (IU/lb.) & $45,415(20,600)$ \\
Vitamin $\mathrm{D}_{3}, \mathrm{IU} / \mathrm{kg}(\mathrm{IU} / \mathrm{lb})$. & $11,356(5,151)$ \\
Vitamin E, IU/kg (IU/lb.) & $220.46(100)$ \\
\hline
\end{tabular}

${ }^{1}$ Manufactured by Land O'Lakes Animal Milk Products Co. (Shoreview, $\mathrm{MN})$.

Disease Center (Ames, IA). Holstein bull calves ( $\mathrm{n}=$ 24) received at least $3.9 \mathrm{~L}$ of colostrum within the first $6 \mathrm{~h}$ postpartum. Navels were dipped in iodine and an Escherichia coli vaccine (Genecol-99, Schering Plough Animal Health, Union, NJ) was administered orally at birth. Calves were housed individually in elevated pens $(1.52 \mathrm{~m}$ long $\times 0.914 \mathrm{~m}$ wide $\times 0.914 \mathrm{~m}$ high $)$ in a temperature-controlled $\left(18^{\circ} \mathrm{C}\right)$ barn. Calf health was monitored and recorded daily. The nutritional management of the calves has been described previously (Foote et al., 2007). On d 0, calves (mean age \pm SEM: 9.1 $\mathrm{d} \pm 2.4 \mathrm{~d}$ ) were weighed and assigned randomly to 3 treatment groups ( 8 calves per treatment) to achieve 3 targeted daily rates of gain $(\mathrm{NG}=0.0 \mathrm{~kg} / \mathrm{d}, \mathrm{LG}=$ $0.55 \mathrm{~kg} / \mathrm{d}$, or $\mathrm{HG}=1.2 \mathrm{~kg} / \mathrm{d}$ ) in live weight over a 7 -wk period. Milk replacer intakes required to achieve the targeted growth rates were estimated using the NRC computer program (NRC, 2001). All calves were fed a $30 \%$ CP, 20\% fat, all milk protein MR (Land O'Lakes Inc., Shoreview, MN) reconstituted to $14 \% \mathrm{DM}$ as described previously (Foote et al., 2007). Composition of the MR is provided in Table 1.

Calves were bucket-fed twice daily (0700 and 1800 h) and offered water ad libitum. Starter grain was not offered. Amounts of MR offered and refused were recorded at each feeding. Calves were weighed weekly and the amount of MR fed was adjusted at these times to compensate for changes in live weight. Because vitamin concentrations in the MR were based on DMI of HG calves, the NG and LG calves were supplemented with additional vitamins $\mathrm{A}, \mathrm{D}$, and $\mathrm{E}$ once weekly to compensate for their reduced consumption of MR. In contrast, mineral intakes by NG and LG were not adjusted for their reduced consumption of MR.

Sera for haptoglobin, vitamin, and mineral analyses were obtained weekly by jugular venipuncture. These were collected in the morning after a fasting period of approximately $12 \mathrm{~h}$. Haptoglobin concentrations ( $\mu \mathrm{g} /$ $\mathrm{mL}$ ) were determined using a immunoperoxidase-based 
ELISA kit (Immunology Consultants Laboratory Inc., Newberg, OR) according to the manufacturer's instructions. Assay standards were 1,000, 500, 250, 125, and $62.5 \mathrm{ng} / \mathrm{mL}$. Test samples were undiluted to ensure absorbance of samples was within the standard curve.

Serum VitA and VitE concentrations were determined by reverse-phase HPLC (Ametaj et al., 2000) using a modification of a method originally described by Kaplan et al. (1987). Serum VitD was quantified by radioimmunoassay using a method described by Hollis et al. (1993).

Serum Ca and $\mathrm{Mg}$ concentrations were determined by atomic absorption spectrometry as described previously (Waldron et al., 2003). Serum P was determined using a procedure modified from Parekh and Jung (1970), validated in our laboratory, and described in detail by Waldron et al. (2003). Serum Zn and Cu concentrations were analyzed by atomic absorption spectrometry (AAnalyst 100 atomic absorption spectrometer, Perkin Elmer Inc., Wellesley, MA). Zinc standards were prepared by dissolving zinc metal $(125 \mathrm{mg})$ in $\mathrm{HCl}(6 \mathrm{M}$, $6 \mathrm{~mL}$ ) and then increasing the volume to $250 \mathrm{~mL}$ using $1 \% \mathrm{HCl}$. A 1:100 dilution of this was diluted further in $22.5 \%$ glycerol to yield $0.5,1.0$, and $1.5 \mu \mathrm{g} / \mathrm{mL}$ standards. The $0 \mu \mathrm{g} / \mathrm{mL}$ standard consisted of $22.5 \%$ glycerol without $\mathrm{Zn}$. In the assay, $0.5 \mathrm{~mL}$ of standards and test sera were diluted in $1 \mathrm{~mL}$ of water. Standards, test samples, and an internal laboratory standard (0.82 $\mu \mathrm{g} / \mathrm{mL}$ ) were run in duplicate. The spectrometer was operated with a 2 -nm slit-width, $213.9 \mathrm{~nm}$ wavelength, and lamp current of $15 \mathrm{~mA}$. Zinc concentrations in test samples were expressed as micrograms of Zn per milliliter. Copper standards were prepared by dissolving $\mathrm{Cu}$ metal $(250 \mathrm{mg})$ in $\mathrm{HNO}_{3}(8.5 \mathrm{M}, 6 \mathrm{~mL})$ and then increasing the volume to $250 \mathrm{~mL}$ using water. A 1:100 dilution of this was diluted further in $20 \%$ glycerol to yield $0.5,1.0$, and $1.5 \mu \mathrm{g} / \mathrm{mL}$ standards. The $0 \mu \mathrm{g} / \mathrm{mL}$ standard consisted of $20 \%$ glycerol without $\mathrm{Cu}$. In the assay, $0.5 \mathrm{~mL}$ of standards and test sera were diluted in $0.5 \mathrm{~mL}$ of water. Standards, test samples, and an internal laboratory standard $(0.85 \mu \mathrm{g} / \mathrm{mL})$ were run in duplicate. The spectrophotometer was operated with a 0.7-nm slit-width, $324.8 \mathrm{~nm}$ wavelength, and lamp current of $15 \mathrm{~mA}$. Copper concentrations in test samples were expressed as micrograms of $\mathrm{Cu}$ per milliliter.

Data were analyzed as a completely randomized design (Statview software, version 5.0, SAS Institute Inc., Cary, NC). Calf served as the experimental unit in the analysis of all data. Fat-soluble vitamin, mineral, and haptoglobin concentrations were analyzed as a split-plot with repeated-measures ANOVA. The model included fixed effects of growth rate (NG, LG, or HG), time (week of experiment), and treatment $\times$ time interaction, and calf was included in the model as the random effect. Fisher's protected LSD test was applied when effects $(P<0.10)$ were detected.

Growth performance, health, and immune function data for these calves have been reported previously (Foote et al., 2007). To summarize, calf weights were not different at the beginning of the study (wk 0) and averaged $45.7 \mathrm{~kg}$. Mean growth rates for NG $(0.11 \mathrm{~kg} / \mathrm{d})$, LG $(0.58 \mathrm{~kg} / \mathrm{d})$, and HG $(1.16 \mathrm{~kg} / \mathrm{d})$ calves during the 7-wk study differed $(P<0.0001)$; at the conclusion of the treatment period, BW of NG, LG, and HG calves were $51.4(\mathrm{SEM} \pm 0.7), 78.6( \pm 2.6)$, and $111.6( \pm 1.9)$ $\mathrm{kg}$, respectively. Several calves were treated for scours or respiratory illness during the experimental period. Five HG calves and $2 \mathrm{NG}$ calves required treatment for scours, whereas LG calves did not manifest symptoms of diarrhea. Three HG calves were also treated for respiratory illness. The LG or NG calves did not manifest symptoms of respiratory illness during the study. Symptoms typically considered indicative of fat-soluble and mineral deficiencies were not evident in any of the calves during the experimental period.

Haptoglobin is one of several acute-phase proteins produced in response to inflammatory changes associated with infection, making it a potentially useful indicator of calf health (Grell et al., 2005). Serum haptoglobin concentrations were unaffected by growth rate $(P>0.05$; Figure 1$)$ and the haptoglobin $\times$ time interaction was not significant $(P=0.54)$, suggesting that the symptoms of respiratory illness in HG calves and scours in LG and HG calves were not of sufficient severity to induce measurable treatment differences in haptoglobin concentrations.

Both NG and LG calves were supplemented orally with additional amounts of VitA, VitD, and VitE weekly to compensate for their reduced consumption of MR relative to that of $\mathrm{HG}$ calves. Using this approach, all calves received approximately the same amounts of these vitamins. Serum VitA, VitE, and VitD concentrations were determined weekly. These data are presented in Figure 2, with Table 2 providing a summary of treatment and time effects and their interaction for all variables. Both VitA and VitD concentrations were unaffected by growth rate. At wk 0 (i.e., pretreatment), concentrations were comparable across the treatment groups and averaged $127.2 \mathrm{ng} / \mathrm{mL}$ for VitA and $42.9 \mathrm{ng} /$ $\mathrm{mL}$ for VitD. These concentrations are typical of those of newborn calves fed adequate colostrum (Rajaraman et al., 1997; Nonnecke et al., 1999). Retinol concentrations increased $(182 \mathrm{ng} / \mathrm{mL} ; P<0.001)$ during the first week and averaged $178 \mathrm{ng} / \mathrm{mL}$ by the conclusion of the study. Plasma VitD increased progressively during the experimental period and averaged $79.8 \mathrm{ng} / \mathrm{mL}$ by wk 7. Both VitA and VitD concentrations were within the normal ranges for 2-mo-old Holstein calves. 


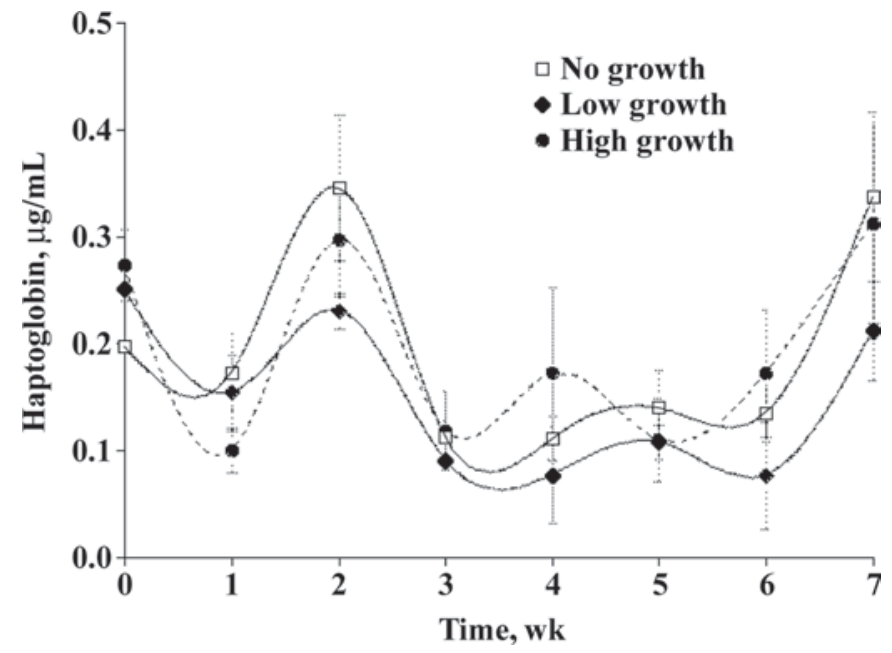

Figure 1. Serum concentrations $(\mu \mathrm{g} / \mathrm{mL}$, means \pm SEM) of haptoglobin in preruminant dairy calves fed to achieve no, low, and high growth rates $(\mathrm{n}=8 /$ treatment $)$. Calf age (mean $\pm \mathrm{SE})$ at the beginning of the treatment period (wk 0) was $9.1 \pm 2.4 \mathrm{~d}$. Treatment effect and treatment $\times$ time interaction were not significant, $P>0.05$.

Serum VitE concentrations (Figure 2b), however, were affected by growth rate. Concentrations, by treatment group, were not different at the beginning of the study and averaged $1,934 \mathrm{ng} / \mathrm{mL}$ for all calves; however, by wk 6 the mean concentration in LG calves exceeded the mean concentration in $\mathrm{HG}$ calves $(4,348 \mathrm{ng} / \mathrm{mL}$ vs. $2,049 \mathrm{ng} / \mathrm{mL})$ and by wk 7 concentrations in LG $(3,442$ $\mathrm{ng} / \mathrm{mL})$ and NG $(3,090 \mathrm{ng} / \mathrm{mL})$ calves exceeded $(P<$ $0.05)$ that in $\mathrm{HG}$ calves $(1,774 \mathrm{ng} / \mathrm{mL})$. The wk 7 value in $\mathrm{HG}$ calves was substantially below the $3,000 \mathrm{ng} / \mathrm{mL}$ (Weiss et al., 1997) considered necessary for optimal health in adult cows. Results from a previous study (Foote et al., 2003) considering the effects of growth on fat-soluble vitamin status of preruminant calves suggest that the increased growth rate associated with feeding an intensified diet results in lower serum VitE concentrations. Calves in the latter study (Foote et al., $2003)$ were fed a standard $(0.45 \mathrm{~kg} / \mathrm{d}$ of a $22 \% \mathrm{CP}$, $20 \%$ fat MR) or an intensified $(1.14 \mathrm{~kg} / \mathrm{d}$ of a $28 \%$ CP, $20 \%$ fat MR) diet until 8 wk of age, with calf starter fed ad libitum to intensified calves and limit-fed to calves on the standard diet. Using this approach, gain of the intensified-fed calves $(0.58 \mathrm{~kg} / \mathrm{d})$ exceeded by more than 2 -fold the gain of standard-fed calves $(0.26 \mathrm{~kg} / \mathrm{d})$. Although the approaches used to control growth rate differed between studies, results from both studies suggest an association between growth rate and VitE status and may indicate a need for increasing the amount of VitE in MR-fed calves in nutrition programs promoting high growth rates. Another consideration is the role of colostrum in promoting optimal VitE status in newborn calves (Rajaraman et al., 1997). In the pres-
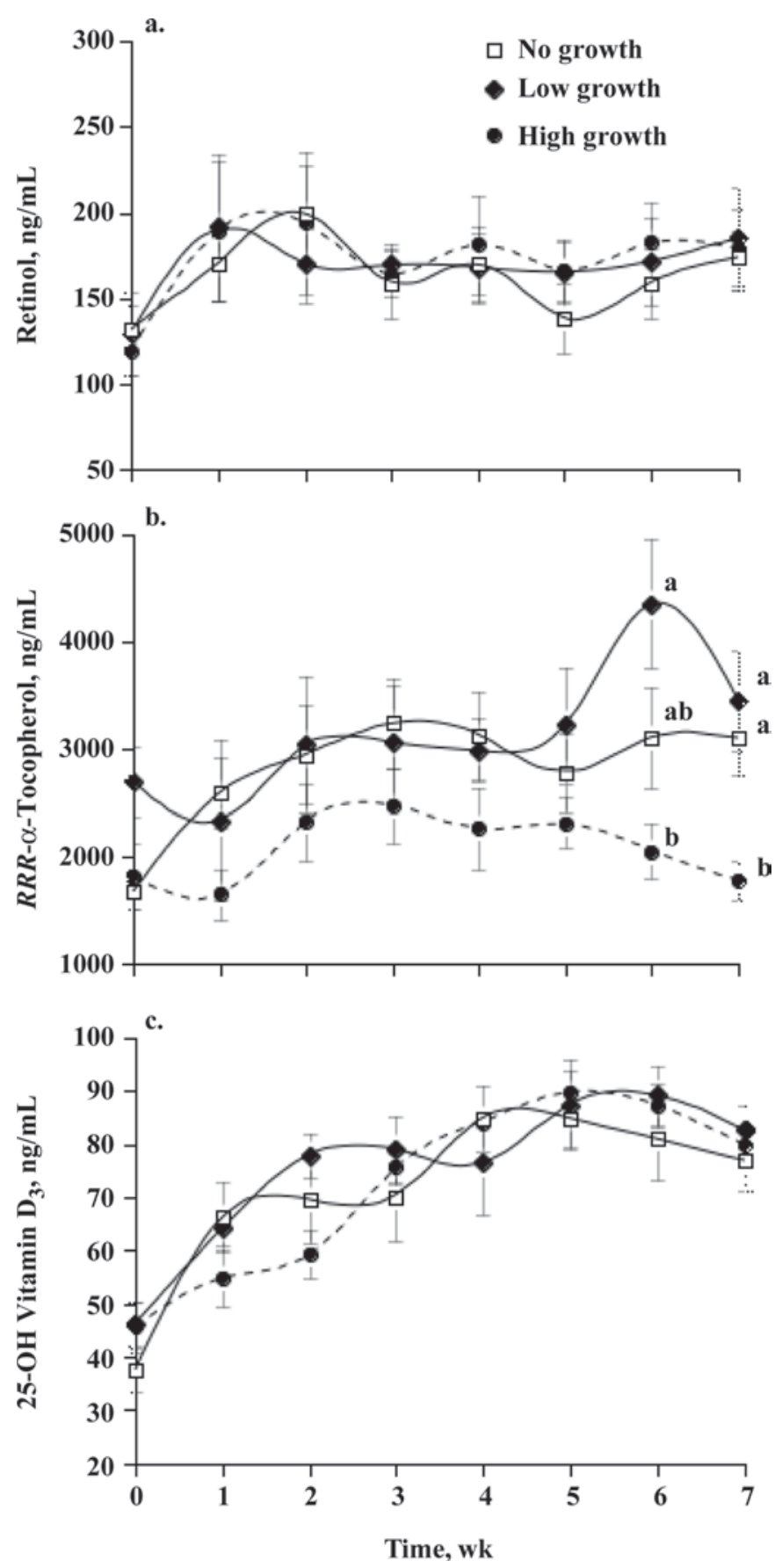

Figure 2. Serum concentrations (ng/mL, means $\pm \mathrm{SEM}$ ) of (a) vitamin A (retinol), (b) vitamin $\mathrm{E}(R R R$ - $a$-tocopherol), and (c) vitamin $\mathrm{D}$ (25-hydroxyvitamin $\mathrm{D}_{3}$ ) in preruminant dairy calves fed to achieve no, low, and high growth rates $(\mathrm{n}=8 /$ treatment $)$. No-growth and low-growth calves received additional supplementation with vitamins $\mathrm{A}, \mathrm{D}$, and $\mathrm{E}$ once weekly to compensate for their reduced consumption of milk replacer relative to high-growth calves. ${ }^{a, b}$ Treatment means at specific times with different letters differ, $P<0.05$. 
Table 2. Results ( $P$-values) from repeated-measures ANOVA for metabolic response variables ${ }^{1}$

\begin{tabular}{lccc}
\hline Variable & Treatment effect & Time effect & Interaction \\
\hline Retinol, $\mathrm{ng} / \mathrm{mL}$ & $\mathrm{NS}$ & $<0.0001$ & $\mathrm{NS}$ \\
$R R R$ - $\alpha$-Tocopherol, $\mathrm{ng} / \mathrm{mL}$ & $\mathrm{NS}$ & $<0.0001$ & $<0.001$ \\
$25-(\mathrm{OH})$-vitamin $\mathrm{D}_{3}, \mathrm{ng} / \mathrm{mL}$ & $\mathrm{NS}$ & $<0.0001$ & $\mathrm{NS}$ \\
Copper, $\mathrm{mg} / \mathrm{dL}$ & 0.05 & $<0.05$ & $<0.01$ \\
Zinc, $\mathrm{mg} / \mathrm{dL}$ & $\mathrm{NS}$ & $<0.001$ & $\mathrm{NS}$ \\
Calcium, mg/dL & $<0.05$ & $<0.0001$ & $<0.001$ \\
Magnesium, mg/dL & $\mathrm{NS}$ & $<0.01$ & $<0.05$ \\
Phosphorous, mg/dL & $<0.001$ & $\mathrm{NS}$ & $<0.05$ \\
Haptoglobin, $\mathrm{mg} / \mathrm{mL}$ & $\mathrm{NS}$ & $<0.0001$ & $\mathrm{NS}$ \\
\hline
\end{tabular}

${ }^{1}$ Variables characterized responses of preruminant dairy calves to 3 dietary regimens producing no, low, and high growth rates during the 8 -wk study.

${ }^{2} \mathrm{NS}=P \geq 0.05$

ent study, all calves received adequate colostrum that contributed substantially to the relatively high VitE concentrations at the beginning of the study. Conceivably, the VitE status of HG calves in the present study would have been compromised further if they had not received colostrum. Mechanisms underlying the association between growth rate and vitamin E status warrant investigation.

Serum mineral concentrations in NG, LG, and HG calves from wk 0 through wk 7 are shown in Figures 3 and 4 . Because no attempt was made to adjust mineral supplementation in NG and LG calves to approximate levels consumed by HG calves due to increased MR intake, the expectation was that serum mineral concentrations would be higher in HG calves during the latter stages of the study. This was the case for serum $\mathrm{Ca}$ (Figure 3a), P (Figure 3c), and $\mathrm{Cu}$ (Figure 4a). Serum $\mathrm{Ca}$ concentrations in $\mathrm{HG}$ calves were higher than those in NG calves from wk 4 to wk 7, and higher than those in LG calves at wk 6 and wk 7; however, concentrations for all treatment groups remained within the normal range for young calves (approximately 9 to $10.5 \mathrm{mg} / \mathrm{dL}$; NRC, 2001). Mean Ca concentrations in HG, LG, and NG calves at wk 7 were $10.01,9.62$, and $9.21 \mathrm{mg} / \mathrm{dL}$, respectively. Serum $\mathrm{P}$ concentrations for all treatment groups (Figure 3c) remained within the normal range (4 to $8 \mathrm{mg} / \mathrm{dL}$; NRC, 2001) during the study period; however, concentrations in HG calves exceeded those in NG and LG calves from wk 2 to wk 7 . Mean P concentrations in HG, LG, and NG calves at the conclusion of the study were $6.79,5.72$, and $5.08 \mathrm{mg} / \mathrm{dL}$, respectively. Serum $\mathrm{Cu}$ concentrations in all calves remained within the normal range for healthy preruminant calves $(0.7$ to $1.3 \mu \mathrm{g} / \mathrm{mL}$; Suttle, 1986), although concentrations in NG and LG calves approached the lower end $(<0.71$ $\mu \mathrm{g} / \mathrm{mL}$ ) of this range on several occasions during the study (Figure 4a). Mean $\mathrm{Cu}$ concentrations in HG, LG, and NG calves at wk 7 were $0.87,0.72$, and $0.74 \mu \mathrm{g} /$ $\mathrm{mL}$, respectively, and were several fold higher than con- centrations $(<0.2 \mu \mathrm{g} / \mathrm{mL}$; NRC, 2001) associated with symptoms of deficiency.

In contrast to the pattern observed for serum $\mathrm{Ca}$, $\mathrm{P}$, and $\mathrm{Cu}$ concentrations, serum $\mathrm{Mg}$ (Figure $3 \mathrm{a}$ ) and Zn (Figure 4b) concentrations in HG calves were not higher than those in LG and NG calves at any time during the 7-wk study, even though amounts of MR consumed by HG calves were substantially greater than those fed to LG and NG calves. The Mg concentrations in HG calves were not different from those in LG calves at any time and were lower than concentrations in NG calves from wk 2 to wk 5. The mean $\mathrm{Mg}$ concentration $(1.84 \mu \mathrm{g} / \mathrm{mL})$ in $\mathrm{HG}$ calves during this period approached the lower limit of the normal range for adult dairy cattle (1.8 to $2.4 \mu \mathrm{g} / \mathrm{mL}$ ) and was substantially lower than the normal range for young dairy calves $(2.2$ to $2.7 \mu \mathrm{g} / \mathrm{mL}$ ). The sustained, low $\mathrm{Mg}$ concentrations in HG calves, however, were considerably higher than concentrations associated with clinical deficiency $(<0.7$ $\mu \mathrm{g} / \mathrm{mL}$; Roy, 1990). Given the importance of $\mathrm{Mg}$ in bone mineral formation (i.e., early skeletal growth) and the comparatively low $\mathrm{Mg}$ concentrations in $\mathrm{HG}$ calves in the present study, reevaluation of $\mathrm{Mg}$ levels in milk replacers used in nutrition programs promoting high growth rates in preruminant calves may be warranted.

Serum Zn concentrations in HG, LG, and NG calves were comparable throughout the study and not different at any sampling time (Figure $4 \mathrm{~b}$ ). For all treatment groups, $\mathrm{Zn}$ concentrations remained within the middle to higher end of the normal range for growing calves (0.7 to $1.3 \mu \mathrm{g} / \mathrm{mL}$ ) throughout the study period.

In conclusion, serum vitamin and mineral concentrations in NG, LG, and HG calves remained within ranges considered normal for young growing calves. Serum $R R R$ - $\alpha$-tocopherol concentrations were lowest in $\mathrm{HG}$ calves, suggesting an association between growth rate and vitamin E status. Additional research is necessary to determine if there is a need for increased amounts of vitamin $\mathrm{E}$ in milk replacers fed to calves managed 

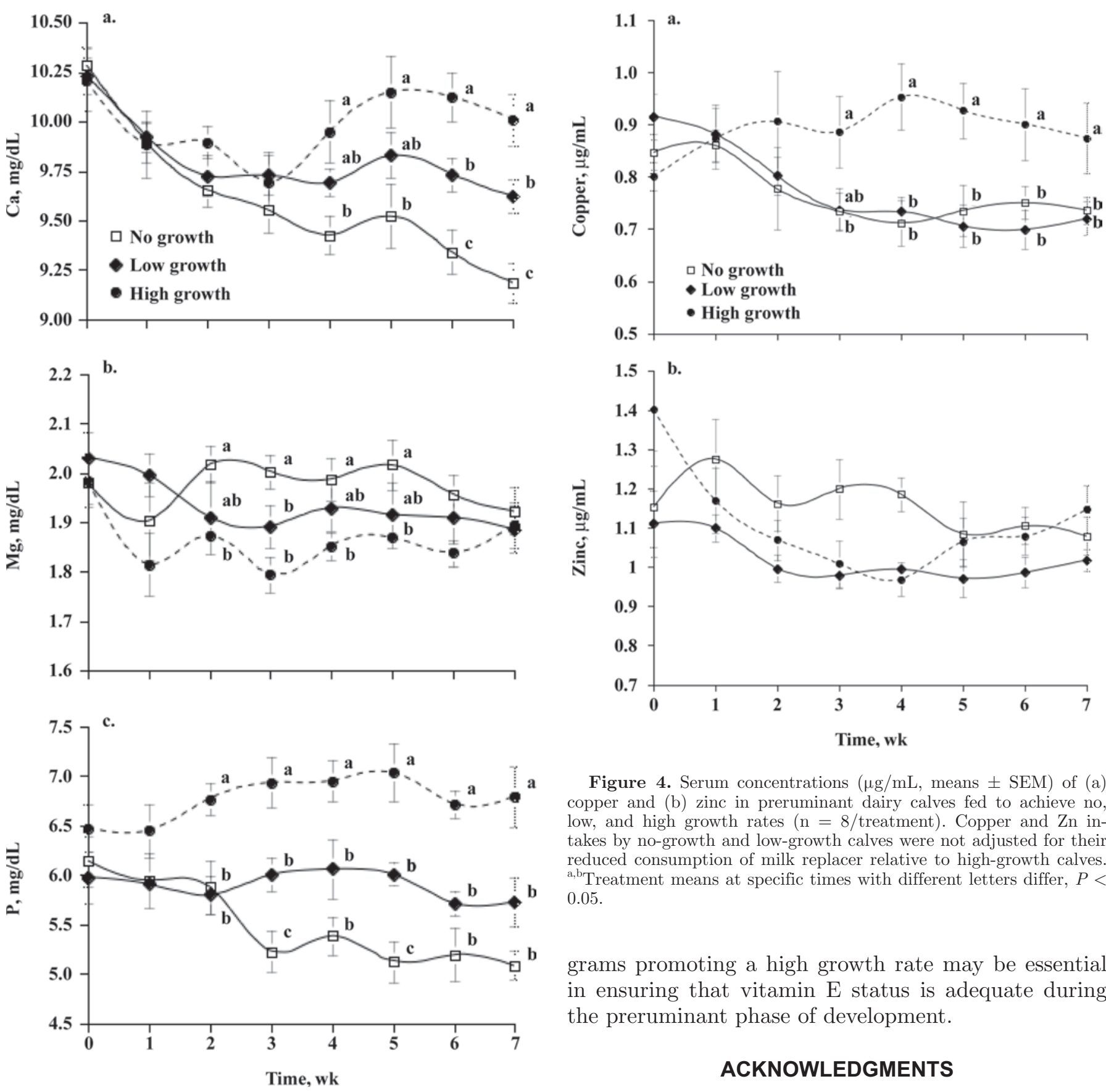

Figure 4. Serum concentrations $(\mu \mathrm{g} / \mathrm{mL}$, means \pm SEM) of (a) copper and (b) zinc in preruminant dairy calves fed to achieve no, low, and high growth rates $(\mathrm{n}=8 /$ treatment $)$. Copper and $\mathrm{Zn}$ intakes by no-growth and low-growth calves were not adjusted for their reduced consumption of milk replacer relative to high-growth calves. ${ }^{\mathrm{a}, \mathrm{b}}$ Treatment means at specific times with different letters differ, $P<$ 0.05 .

grams promoting a high growth rate may be essential in ensuring that vitamin $\mathrm{E}$ status is adequate during the preruminant phase of development.

\section{ACKNOWLEDGMENTS}

Figure 3. Serum concentrations $(\mathrm{mg} / \mathrm{dL}$, means \pm SEM) of (a) calcium, (b) magnesium, and (c) phosphorous in preruminant dairy calves fed to achieve no, low, and high growth rates ( $\mathrm{n}=8 /$ treatment). Calcium, $\mathrm{Mg}$, and $\mathrm{P}$ intakes by no-growth and low-growth calves were not adjusted for their reduced consumption of milk replacer relative to high-growth calves. ${ }^{\text {a-c }}$ Treatment means at specific times with different letters differ, $P<0.05$.

nutritionally to promote high growth rates. Experimental evidence regarding the contribution of colostrum to the vitamin E status of the newborn calf (Rajaraman et al., 1997) suggests that feeding fresh, high quality colostrum to newborns destined for nutritional pro-

The authors thank N. Eischen, D. Hoy, and D. Zimmerman for technical support, and E. Miller, A. Moser, and P. Amundson (all of National Animal Disease Center, Ames, IA) for animal care.

\section{REFERENCES}

Ametaj, B. N., B. J. Nonnecke, S. T. Franklin, R. L. Horst, W. R. Bidlack, R. L. Stuart, and D. C. Beitz. 2000. Dietary vitamin A modulates the concentration of $R R R$ - $\alpha$-tocopherol in plasma lipoproteins from calves fed milk replacer. J. Nutr. 130:629-636. Foote, M. R., B. J. Nonnecke, D. C. Beitz, and W. R. Waters. 2007. High growth-rate fails to enhance adaptive immune responses 
of neonatal calves and is associated with reduced lymphocyte viability. J. Dairy Sci. 90:404-417.

Foote, M. R., B. J. Nonnecke, W. R. Waters, M. Fowler, B. L. Miller, T. Johnson, B. Perry, and D. C. Beitz. 2003. Effect of age and accelerated growth on circulating concentrations of b-carotene and vitamins A, E, and D in milk replacer-fed calves. J. Dairy Sci. 86(Suppl. 1):309. (Abstr.)

Goff, J. P. 2004. Macromineral disorders of the transition cow. Vet. Clin. Food Anim. 20:471-497.

Goff, J. P., K. Kimura, and R. L. Horst. 2001. Effects of mastectomy on milk fever, energy, and vitamins A, E, and b-carotene at parturition. J. Dairy Sci. 85:1427-1436.

Grell, S. N., K. Tjørnehøj, L. E. Larsen, and P. M. H. Heegard 2005. Marked induction of IL-6, haptoglobin and INFy following experimental BRSV infection in young calves. Vet. Immunol. Immunopathol. 103:235-245.

Hollis, B. W., J. Q. Kamerud, S. R. Selvaag, J. D. Lorenz, and J. L. Napoli. 1993. Determination of vitamin D status by radioimmunoassay with a ${ }^{125}$ I-labeled tracer. Clin. Chem. 39:529533.

Horst, R. L., J. P. Goff, and T. A. Reinhardt. 1994. Calcium and vitamin D metabolism in the dairy cow. J. Dairy Sci. 77:19361951.

Kaplan, L. A., J. A. Miller, and E. A. Stein. 1987. Simultaneous measurement of serum retinol, tocopherols, carotenes, and carotenoids by high performance liquid chromatography. J. Clin. Lab. Anal. 1:147-152.

NRC. 2001. Nutrient Requirements of Dairy Cattle. 7th rev. ed. National Academy Press, Washington, DC.
Nonnecke, B. J., R. L. Horst, W. R. Waters, P. Dubeski, and J. A. Harp. 1999. Modulation of fat-soluble vitamin concentrations and blood mononuclear leukocyte populations in milk replacerfed calves by dietary vitamin A and $\beta$-carotene. J. Dairy Sci. 82:2632-2641.

Nonnecke, B. J., T. A. Reinhardt, and W. R. Waters. 2009. The preruminant calf as a model for characterizing the effects of vitamin D in the neonate. J. Dairy Sci. 92:5692-5696.

Parekh, A. C., and D. H. Jung. 1970. Serum inorganic phosphorous determination using p-phenylenediamine as a reducing agent. Clin. Chim. Acta 27:373-377.

Rajaraman, V., B. J. Nonnecke, and R. L. Horst. 1997. Effects of replacement of native fat in colostrum and milk with coconut oil and fat-soluble vitamins in serum and immune function in claves. J. Dairy Sci. 80:2380-2390.

Roy, J. H. B. 1990. Miscellaneous infections, metabolic disorders, nutritional deficiencies and poisoning. Pages $181-210$ in The Calf Vol. 1: Management of Health. 5th rev. ed. Butterworth's, London, UK.

Suttle, N. R. 1986. Copper deficiency in ruminants: Recent developments. Vet. Rec. 22:519-522.

Waldron, M. R., B. J. Nonnecke, T. Nishida, R. L. Horst, and T. R. Overton. 2003. Effect of lipopolysaccharide infusion on serum macromineral and vitamin $\mathrm{D}$ concentrations in dairy cows. J. Dairy Sci. 86:34440-34446.

Weiss, W. P., J. S. Hogan, D. A. Todhunter, and K. L. Smith. 1997. Effect of vitamin E supplementation in diets with low selenium on mammary gland health of dairy cows. J. Dairy Sci. 80:17281737 